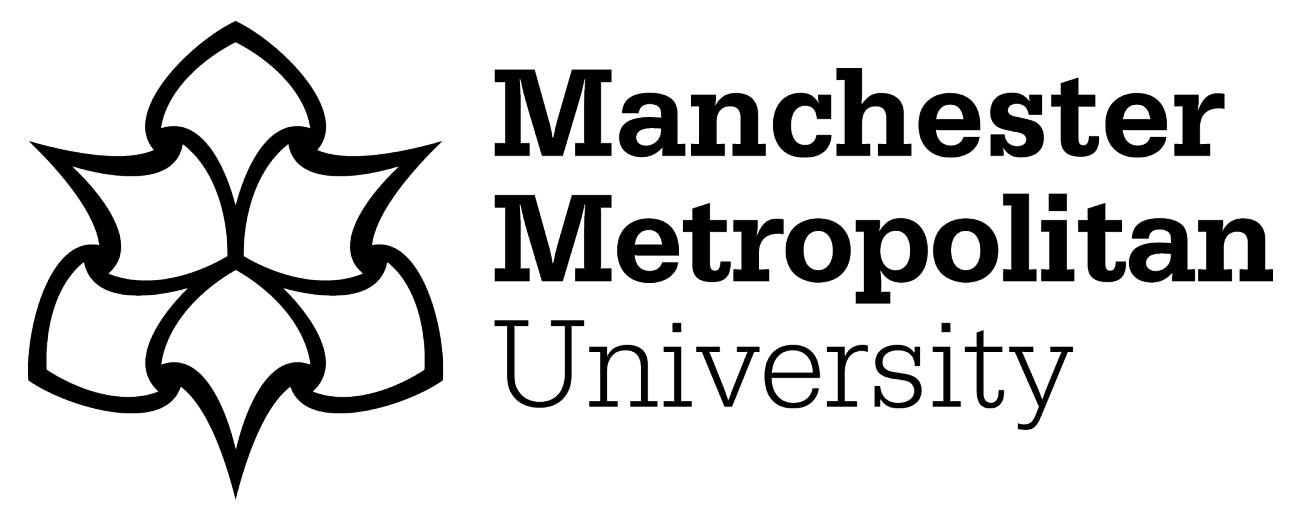

Nguyen, Mai ORCID logoORCID: https://orcid.org/0000-0003-1276-8589 and Walkinshaw, lan (2018) Autonomy in teaching practice: Insights from Vietnamese English language teachers trained in Inner-Circle countries. Teaching and Teacher Education, 69. pp. 21-32. ISSN 0742-051X

Downloaded from: https://e-space.mmu.ac.uk/624224/

Version: Accepted Version

Publisher: Elsevier

DOI: https://doi.org/10.1016/j.tate.2017.08.015

Usage rights: Creative Commons: Attribution-Noncommercial-No Derivative Works 4.0

Please cite the published version 
Cite this paper as

Nguyen, X. N. C. M., \& Walkinshaw, I. (2018). Autonomy in teaching practice: Insights from Vietnamese English language teachers trained in Inner-Circle countries. Teaching and Teacher Education, 69(Supplement C), 21-32. https://doi.org/10.1016/j.tate.2017.08.015

\title{
Autonomy in teaching practice: Insights from Vietnamese English language teachers trained in Inner-Circle countries
}

\begin{abstract}
:
This study investigated the degree to which TESOL (Teaching English to Speakers of Other Languages) training in Inner-Circle English-speaking countries impacted on the autonomy in teaching practice of Vietnamese teachers of English. Using an online survey, semi-structured in-depth interviews, and classroom observations, the research explored tension faced by these teachers when attempting to exercise their autonomy after returning to their local institution, and revealed how they managed to operate within constraints. This paper has significant implications for a range of stakeholders involved in the professional development of non-Inner-Circle TESOL teachers trained in Inner Circle contexts.
\end{abstract}

\section{Keywords:}

Autonomy; English language teaching; language teacher education; Vietnam

\section{Introduction}

In the field of Teaching English to Speakers of Other Languages (TESOL), recent decades have witnessed an increasingly popular social phenomenon called international student mobility (UNESCO Institute for Statistics, 2009), whereby TESOL teachers from what Kachru (1985) termed Outer and Expanding Circle countries (where English is not the first language) seek opportunities for professional training in institutions in the Inner Circle (e.g., UK, USA, Canada, Australia, and New Zealand). The relocation of TESOL practitioners to Inner-Circle countries for study does provide them with immersion in an Anglophone milieu, but it also raises issues concerning the applicability of gained knowledge and skills and the overall impact of overseas training (Li \& Edwards, 2013, 2014; Liyanage \& Barlett, 2008), which are not easily assuaged. These issues are located in the schism between the local linguistic, pedagogical and sociocultural settings where teachers live and work, and those in which they undergo their training (Dogancay-Aktuna \& Hardman, 2012). Teachers undertaking these programs are normally trained in Inner-Circle contexts where an 
integrationist approach to education is usual (Holliday, 1994): Teaching tends to be learnercentered and skills-based, and there is maneuverability within the curriculum. But posttraining, their local educational context is more frequently collectionist, characterized by subject-centeredness, structured learning and strict adherence to a curriculum. While these two approaches to education are neither mutually exclusive nor geographically bounded (Holliday, 2008), elements of the collectionist approach are more frequently represented in non-Inner-Circle contexts (Nunan \& Lamb, 1996), creating a challenge to implement integrationist teaching approaches and techniques (see Butler, 2011).

The growing body of research investigating the efficacy of Inner-Circle TESOL teacher education programs in relation to the teaching practice of non-Inner-Circle English teachers upon return has, on the one hand, reported these teachers being able to implement certain aspects of the knowledge and skills learnt from teacher training in their day-to-day teaching. This impact is often reflected through teachers' adoption of learner-centered teaching methods such as the communicative and task-based approaches (Chowdhury \& Phan, 2008, 2014; Li \& Edwards, 2013, 2014; McKnight \& Turner, 1995; Pham, 2004). On the other hand, existing research has revealed tensions in applying learnt knowledge due to a considerable mismatch between theory (what non-Inner-Circle teachers learned in their Inner-Circle programs) and practice (the extent to which they could implement that knowledge in situated pedagogical contexts that they returned to after training) (see Chowdhury \& Phan, 2014; Liyanage \& Barlett, 2008; Pham, 2004). While these studies shed important light on the teaching reality of non-Inner-Circle teachers who returned from training in Inner-Circle contexts, they have tended to cast a broad net, eliciting data on teachers' general experiences rather than more specific foci that characterize teachers' teaching practice. In this respect, Benson (2010) argues that the gap between theory and practice in teacher education is irreconcilable if teachers lack autonomy, which he defines as 'the freedom and internal capacity to exercise discretion in matters of curriculum implementation' (Benson, 2010, p. 260). (The construct of autonomy is further unpacked in Section 3.2.) A more nuanced understanding of autonomy as it relates to language educators, and the variables which impact it, would do much to illuminate the post-training experience of non-Inner-Circle teachers and the associated tensions therein.

Therefore, the present study examines the autonomy in teaching practice of Vietnamese teachers of English who took Master's level TESOL courses in the Inner Circle and returned to teach at tertiary level in Vietnam, a context which is still typically described as belonging to the Expanding Circle (Bautista \& Gonzalez, 2006; Denham, 1992). Given 
that language teaching is highly context-specific (Lamb, 2008), it is important to explore specific polities, particularly under-represented contexts such as Vietnam. The two main aims of this paper are to investigate the extent to which these teachers can exercise autonomy in their day-to-day practice, and to explore the role that teacher training courses play (or perhaps fail to play) in promoting this autonomy. The research findings benefit not only Inner-Circletrained teachers themselves in terms of allowing them to critically reflect on their professional autonomy, but also teacher educators and Inner-Circle TESOL program coordinators regarding the efficacy of teacher training for practitioners based in Expanding Circle countries.

Before continuing, we acknowledge the criticism surrounding Kachru's 'concentriccircle' framework of world Englishes which we have adopted. As Pennycook (2003) points out, the model conceptualizes world Englishes primarily by national boundaries, whereas the worldwide spread of English and its myriad domains of use both as a first and additional language have clearly blurred these boundaries, particularly among Expanding Circle countries (Kirkpatrick, 2012). We therefore confine our use of Kachru's terms Inner Circle, Outer Circle and Expanding Circle to broadly differentiate the contemporary status of English in communities where teacher-training was conducted and those where graduates later returned to practice.

\section{The context of English education in Vietnam}

\subsection{Overview of English teacher education in Vietnam}

Since the Doi Moi economic reforms starting from 1986 when Vietnam began to open its doors to attract foreign investment, English has replaced Russian as the predominant foreign language taught across all educational levels (Hoang, 2010; Wrights, 2002). This in turn has focused a spotlight on how English teachers are trained. English language teachers in Vietnam are officially trained in teacher's colleges that offer three- to four-year training programs designed to enhance their English language skills and equip them with foundational knowledge of language teaching methodology. Masters-level TESOL programs are also offered by national public universities. Besides domestic training, Vietnam's economic reforms have also brought about greater international cooperation in English teacher education. Scholarship schemes exist to support Vietnamese English teachers to pursue Master's and PhD studies in TESOL in Inner Circle countries. Some popular schemes include bilateral aid programs with Australia (AusAID) and New Zealand (NZAID), and the Fulbright Student Program, overseen by the US Congress. Additionally, the Vietnamese 
government has administered scholarship projects to fund tertiary-level English teachers to study in English-speaking countries (Vietnam International Education Department (VIED), 2016). The number of Vietnamese English teachers pursuing higher degrees in Inner-Circle institutions has therefore increased in recent years, particularly among tertiary-level educators.

\subsection{English teaching and learning at tertiary level in Vietnam}

Students majoring in English can study for a bachelor's degree in English linguistics or English teaching. Students may also learn English as a minor, accounting for 10-12\% of their total credit hours (Hoang, 2010). Vietnamese students' motivation for studying English is often instrumental: to study abroad, and to improve their employment prospects after graduation (Do, 1996; Ngo, 2015). Unlike primary and secondary institutions, where textbooks are stipulated by the Ministry of Education and Training (MOET) (T. M. H. Nguyen, 2011), at university level materials are selected by individual universities and departments. Those chosen are often commercial materials by well-known ELT publishers (H. T. Nguyen, Fehring, \& Warren, 2015).

One governmental education policy has affected English language education at university level: the National Foreign Language 2020 Project (NFL2020), which aims to renovate the teaching and learning of foreign languages within the national education system by 2020. The project has created an English competency framework based on the Common European Framework of Reference (CEFR) to ensure that Vietnamese teachers and learners of English are assessed against international standards (Dudzik \& T. N. Q. Nguyen, 2015). It has also created a network of flagship regional foreign language centres at five national universities to provide professional development programs to 80,000 teachers of English in public schools country-wide. Despite these outcomes, the NFL2020 project has met with criticism: questions have been raised about the appropriateness of the CEFR-based framework for non-European educators (V. H. Nguyen \& Hamid, 2015), and the pressure to replace existing language learning materials with CEFR-based resources. Given the current state of teacher mobility and the importance attached to English education in Vietnam, the Vietnamese context promises to be a fertile ground for research into the impact of overseas TESOL training on teachers returning to local practice.

\section{Review of the literature}

\subsection{The impact of overseas training on returned teachers}


Previous studies with teacher-learners from Outer and Expanding Circle countries undergoing TESOL training in Inner-Circle institutions have reported two types of impacts that overseas training had on these teachers' teaching practice. On one hand, they were found to successfully apply certain knowledge and techniques acquired from training to their everyday classroom teaching. Macalister (2016) observed lessons of pre-service Malaysian teachers of English who previously had two years of training in New Zealand, and found that some techniques associated with the New Zealand training (e.g., running dictation) were applied to make the classroom more learner-centered. Similarly, Chinese in-service teachers returning from a three-month professional development course in the UK in Li and Edwards (2013) were found to implement a more constructivist approach to English teaching as a result of the UK-based training. There was also evidence of learnt instructional techniques and strategies adopted and adapted by the teachers (e.g., gapped dictation and project work).

On the other hand, studies conducted with TESOL teachers trained in the Inner Circle have shown evidence of these teachers either experiencing or expecting to experience tensions in applying what they learned in teacher education. International teacher-learners in Yeh's (2011) study anticipated a mismatch between the pedagogical approaches espoused in their US institution and the realities and constraints of their local educational context. Examining Australian TESOL programs, McKnight and Turner (1995) and Liyanage and Barlett (2008) found that teacher-trainees from Asian countries anticipated difficulty adapting learnt knowledge and skills to the local context, due to differing cultural characteristics, availability of resources, and curricular constraints. Participants in Chowdhury and Phan (2008) were similarly realistic about the efficacy of the Australian TESOL program they attended in terms of what learnt content they could expect to apply to their teaching. Additionally, a pertinent unpublished study by Pham Hoa Hiep investigated the overall professional experience of Vietnamese English language teachers returning to their local working environment after overseas training. The teachers, who valued their knowledge and desired to implement it, nonetheless encountered multiple systemic, cultural, contextual and personal constraints, necessitating compromises in pedagogical approach and practice.

The studies outlined above highlight the positive impacts of overseas training on the pedagogical practices of returned teachers, as well as foreground the often-encountered schism between what TESOL teachers learnt during overseas training, and what they were able to implement in their local teaching contexts. Yet two critical gaps exist in research into this area. Firstly, studies often explored the impact of training while it was still going on, rather than after the recipients re-commenced teaching in their local institutions, limiting their 
focus to academic rather than practice-based knowledge. Secondly, the research that has addressed the post-training context (e.g., Li \& Edwards, 2013; Macalister, 2016; Pham, n.d.) has tended to be broad in scope, eliciting data on teachers' general teaching experiences rather than focusing on more specific foci. This gap in research supports investigation of teachers' post-training experiences concentrating on one specific aspect of their teaching practice.

\subsection{The concept of teacher autonomy}

Considering the various constraints reported in previous studies regarding the applicability of learnt knowledge and skills from Inner Circle TESOL programs, and evidence of successful implementation of teaching techniques acquired from overseas training, it can be argued that returned teachers are likely to experience both types of impacts in their teaching practice. Successful implementation could therefore be determined by the extent to which returned teachers were able to exercise their professional freedom within constraints. The construct of teacher autonomy, to which we now turn, is a useful framework for obtaining meaningful information about the pedagogical experiences of overseas-trained teachers post-training. Teacher autonomy has been defined in different ways by different scholars (Smith, 2003). Our review of several previous definitions reveals that teacher autonomy has been conceptualized as comprising two main elements. The first is the professional freedom that is external from teachers themselves and dependent on structural aspects of teaching (e.g., the educational system and the teaching environment) (Benson, 2000; Pearson \& Hall, 1993). Specifically, it refers to how much independence and control the teacher has concerning key aspects of classroom matters, such as lesson planning and student assessment (hereafter structural autonomy). More specifically, according to Pearson and Hall (1993), this structural dimension of teacher autonomy could be categorized into general autonomy, which relates to classroom standards of conduct and personal on-the-job decision making (e.g., scheduling of time in class, selecting learning activities); and curriculum autonomy, which concerns more rigid instructional factors such as selection of teaching materials, and curriculum planning and sequencing.

The second element frequently associated with teacher autonomy is the internal capacity that is built upon the teacher's abilities to operate within contextual constraints (see Benson, 2013; McGrath, 2000). This dimension can be understood as the extent to which individual teachers are able to deal with pedagogical or institutional constraints in their 
teaching environment (Benson, 2006; McGrath, 2000), and their ability to foster learner autonomy (Benson, 2011; Little, 1995, 2000; Trebbi, 2008) (hereafter individual autonomy).

In addition, speaking from the perspective of teacher educators, Smith (2003) adds another dimension to the notion of teacher autonomy, namely teacher-learner autonomy, which emphasizes that teacher education as a form of teacher professional development should aim at developing 'teacher autonomy'. This involves enabling teachers to exercise their autonomy as learners about their profession, such as by involving them in the process of setting learning aims, designing course content, or assessing their own achievements. Smith's viewpoint resonates with those of other researchers who put forward a 'pedagogy for autonomy' in teacher education (Jiménez Raya \& Vieira, 2015), whereby teacher-learners are not just taught about learner autonomy, but are also empowered to build similar autonomy into their own professional practice. Little (1995), for example, says that "Language teachers are more likely to succeed in promoting learner autonomy if their own education has encouraged them to be autonomous" (p. 180).

As the present study aims to investigate the autonomy in teaching practice of teachers who had previously undergone training in the Inner Circle, in this study the construct of teacher autonomy will be explored based on these three above-analysed dimensions. Particularly, we will focus on examining the two sub-constructs of structural teacher autonomy (i.e., general and curriculum autonomy) in relation to the other two inter-related dimensions (individual and teacher-learner autonomy). In doing so, we acknowledge that notions of teacher autonomy are inevitably informed by culture and that care should be taken not to impose a western-oriented idea of autonomy on a non-western context. That said, we agree with Smith (2003) that dimensions that are related to self-directed professional action and development and teacher-learner autonomy, as specified above, are adaptable to a range of teaching contexts.

\subsection{The importance of researching autonomy in teaching practice and in relation to teacher education}

Let us briefly consider the significance of teacher autonomy, which has in recent years gained substantial attention in second language teaching (see Benson, 2006, 2010; Lamb, 2008). Kumaravadivelu's (2006) post-method pedagogy, which exhorts a shift from adherence to established teaching methods to a situated, context-sensitive approach, considers teacher autonomy a central tenet. Furthermore, the degree of teacher autonomy impacts other constructs that constitute the teaching profession: teacher stress, teacher professionalism, 
teacher empowerment, and job satisfaction (Pearson \& Moomaw, 2006). In particular, constraints on autonomy such as lack of professional control and sense of powerlessness have been shown to generate tension, frustration, anxiety, and reduce self-confidence among teachers as well as their job satisfaction and desire to remain in the profession (see Lamb, 2000; La Ganza, 2008). Given these realities, an investigation of teacher autonomy in practice is valuable for understanding teachers' professional lives, as well as facilitating identification of demotivating factors that might negatively affect teachers' work dedication and even more so to TESOL teachers who have experienced substantial contextual changes as they transition from Inner-Circle learning environments to their local teaching context.

In relation to teacher-learner autonomy, empirical research has recently highlighted how teacher education programs can create a self-directed learning environment for their teacher-learners (see Brown, Smith, \& Ushioda, 2007; Jiménez Raya \& Viera, 2015; Smith \& Erdogan, 2008), which is deemed crucial to the development of teaching autonomy. Though extensive, much of this body of work has not focused primarily on the impact of TESOL teacher training programs on the teaching autonomy of their teacher-learners. The dearth of research that investigates the teaching autonomy of English language teachers in relation to teacher education programs (see Benson, 2010) was conducted in contexts where teacherlearners did not experience transition in terms of contexts of teaching and learning. This further justifies the need for research to fill this gap in the literature. Moreover, given the ongoing concern about the efficacy of language teacher training (Freeman, 2009), an investigation of teacher autonomy will do much to reveal the extent to which teacher education can impact on returned teachers' teaching practice, particularly their teaching autonomy.

Against this background, our research addresses the following questions:

1. How do Vietnamese TESOL teachers trained in Inner-Circle countries perceive and exercise their autonomy in teaching practice (i.e., structural autonomy (general and curriculum autonomy), individual autonomy, teacher-learner autonomy)?

2. How does prior teacher education impact on their autonomy?

\section{Methods}

\subsection{Design and participants}

The current study adopts a sequential explanatory mixed methods design (Creswell \& Plano Clark, 2007; Teddlie \& Tashakkori, 2009). This two-phase model was adopted as it allowed for initial collection of quantitative data about the teachers' teaching autonomy, and provided 
qualitative data outlining individual experiences of a sub-sample, thus enhancing the breadth and depth of the inquiry. The quantitative sample comprised 45 full-time lecturers at 12 Vietnamese public universities who had attended one of 15 TESOL programs in Australia, New Zealand, the UK or the USA, the earliest in 1996 and the most recent in 2014. They took part in a survey. Their ages ranged from 26 to $53(M=35.1 ; S D=7.7)$; their teaching experience ranged from 4 to 29 years $(M=12 ; S D=7.3)$.

The qualitative data were obtained from interviews and classroom observations of three participants from a Vietnamese higher education institution (hereafter University K). University K was one of the flagship regional language centers in the Ministry of Education and Training's (MOET) NFL2020 project. The three participants were Hoai, Linh and Thanh, all lecturers or senior lecturers in the Department of English at University K. To optimize descriptive breadth, the three were selected from a pool of teachers who volunteered to be interviewed and observed as they differed considerably in terms of career experience and training pathways: Hoai, 42, had 20 years of teaching experience, a master's degree in TESOL from an American university, and a PhD from a New Zealand university. Linh, aged 31 , had nine years of teaching experience and attended a master's program in TESOL in the USA. Thanh, 26, had four years of teaching experience and completed a TESOL master's program at an Australian university before resuming her position at University K.

\subsection{Data collection instruments and data analysis}

A questionnaire was used to obtain information about the teachers' structural and individual autonomy. The questionnaire was adapted from Pearson and Moomaw's (2006; see also Pearson \& Hall, 1993) Teaching Autonomy Scale (TAS) (Appendix A). The TAS examined two dimensions of teaching autonomy: general autonomy and curriculum autonomy (see Section 3.2). As Pearson and Hall's TAS targeted primary and secondary teachers, whose teaching conditions and students differ from those in higher education, we adjusted some items to make them more relevant to teaching at university level. For instance, a statement on 'teachers' control over students' standards of behaviour' was changed into 'teachers' freedom to set expectations for student learning,' based on the second dimension of teacher autonomy as characterising teachers' ability to foster learner autonomy. Cross-checking items that were similar in meaning but phrased differently were also omitted to reduce response time. Our adapted TAS therefore has 11 statements (instead of 18 as in Pearson and Moomaw's (2006) instrument): four items for measuring curriculum autonomy, and seven for general autonomy. These two constructs were measured on a 5-point Likert scale (1 being 'strongly disagree' 
and 5 being 'strongly agree'). The Cronbach's $\alpha$ values for internal consistency reliability of these constructs are .71 for curriculum autonomy, and .60 for general autonomy, which are considered acceptable. Regarding delivery, the questionnaire was distributed online through a university-based webpage using a snowball sampling technique (see Dörnyei, 2007). Fortyfive valid responses were garnered. After data-collection, results were analyzed using SPSS 22.0. The participants' total autonomy scores were calculated by adding the points of all items measuring general and curriculum autonomy. Basic statistics (mean + standard deviation) were then computed to obtain an average autonomy score. Additionally, to identify any statistically significant difference between the teachers' perceived general and curriculum autonomy, the data were normalized, tested for normal distribution, and compared using a Wilcoxon signed-rank test for non-normally distributed data.

Interviews were employed to explore the second and third dimension of teacher autonomy (capacity for self-directed teaching and autonomy as teacher-learners), as well as to uncover the impact of overseas training on teaching autonomy. The interview questions (Appendix B) were based on the survey responses and probed the extent of participants' perceived autonomy in their teaching practice and their capacity to exercise their autonomy within constraints as well as the impact of overseas TESOL training. Collected interview data were transcribed verbatim and coded according to three levels of qualitative content analysis (Berg, 2007; Dörnyei, 2007): (1) segments relating to teacher autonomy were identified; (2) relevant segments were coded according to emerging concepts and issues; (3) the data were compared across the three interviews to identify common themes, following Strauss and Corbin's (1990) constant comparative method. Additionally, member-checking was utilised to ensure the trustworthiness of the interview analysis. The key themes that emerged from the three interviews were summarised and sent to each participant along with interview transcripts to confirm that the analysed data accurately reflected their views.

Two classroom observation sessions, equivalent to four hours of teaching, were conducted with each of the three teachers over a four-week period. The observation was to triangulate teachers' responses in the questionnaire and interviews. The first author took a non-participant role in observation and kept field notes of events, which were then fleshed out into narrative observation transcripts. Observed teachers then participated in retrospective interview sessions, in which they were asked to reflect on their classroom behaviors during critical events that occurred. The observational data were analysed based on what Borg (2006) termed key instructional episodes; in the current study, these were classroom incidents that demonstrated or challenged the teachers' autonomy in practice. The retrospective 
interviews were analyzed according to the interview analysis procedure outlined above. Table 1 provides a summary of the research methodology of the current study.

Table 1. Summary of research methodology

\begin{tabular}{|c|c|c|}
\hline Research question (RQ) & Data collection instrument & Data analysis \\
\hline $\begin{array}{l}\text { RQ1: teachers' perceived } \\
\text { autonomy (structural/ } \\
\text { individual/teacher-learner } \\
\text { autonomy) }\end{array}$ & $\begin{array}{l}\text { Questionnaire } \\
\text { Interview } \\
\text { Classroom observation } \\
\text { followed by retrospective } \\
\text { interviews }\end{array}$ & $\begin{array}{l}\text { Descriptive and inferential } \\
\text { statistics } \\
\text { Content analysis } \\
\text { Key instructional episodes }\end{array}$ \\
\hline $\begin{array}{l}\text { RQ2: impact of overseas } \\
\text { training on teacher } \\
\text { autonomy }\end{array}$ & $\begin{array}{l}\text { Interview } \\
\text { Classroom observation } \\
\text { followed by retrospective } \\
\text { interviews }\end{array}$ & $\begin{array}{l}\text { Content analysis } \\
\text { Key instructional episodes }\end{array}$ \\
\hline
\end{tabular}

\subsection{Role of the researchers}

We here address the potential for designer bias in the research design and interpretation. Some subjectivity is unavoidable in a partly qualitative inquiry; indeed, the first author shared the participants' professional and educational background, making it impossible to entirely 'divorce [herself] from the experiences of the participants' (Park, 2012, p. 131). Subjectivity was minimised in the design through construction of neutrally-phrased interview and questionnaire items (the latter adapted from an established survey instrument - see Section 4.2) as well as a member-checking protocol.

\section{Results}

The research findings are presented according to the teachers' perceptions of the three dimensions of teacher autonomy. We first present findings about the degree of freedom/constraint in several aspects of teaching practice (structural autonomy), particularly general and curriculum autonomy, followed by teachers' capacity to operate within general and curricular constraints (individual autonomy). The impact of prior overseas training on the perception and exercise of teacher autonomy was also demonstrated most clearly in this dimension of teacher autonomy. Finally, the extent to which the teachers were allowed to be autonomous learners (teacher-learner autonomy) is reported.

\subsection{Teachers' degree of structural autonomy}


How did the Vietnamese TESOL teachers rate themselves in terms of teaching autonomy? Table 2 presents descriptive statistics for the surveyed teachers' autonomy scores. Overall, the participants rated themselves relatively highly, with a mean of 38.2.

Table 2. Teacher autonomy mean and standard deviation

\begin{tabular}{lll}
\hline$n$ & $\mathrm{M}$ & $\mathrm{SD}$ \\
\hline 45 & 38.2 & 2.07
\end{tabular}

Note. Maximum score $=55$ (11 statements measured on a 5-point Likert scale)

If we break this score down into the two sub-constructs of general autonomy and curriculum autonomy (see Section 3.2) however, differences emerge. Figure 1 shows that the greatest scope for decision-making lay with classroom events such as 'setting expectations for students' learning' $(M=4.44, S D=0.59)$, 'scheduling of use of time in class' $(M=4.27$, $S D=0.54)$, 'selecting learning activities' $(M=4.18, S D=0.61)$, and 'using classroom space' $(M=4.04, S D=0.74)$. 'Designing own assessment' rates lowest among the constructs associated with general autonomy $(\mathrm{M}=3.47, S D=0.81)$. Yet even this relatively low rating exceeds the teachers' self-ratings of curriculum autonomy, with the reported average rating of most items placing below the middle value (3.0) of the 5-point Likert scale for that construct. The highest rating item for curriculum autonomy was 'deciding teaching guidelines and procedures' $(\mathrm{M}=3.02, S D=0.62)$.

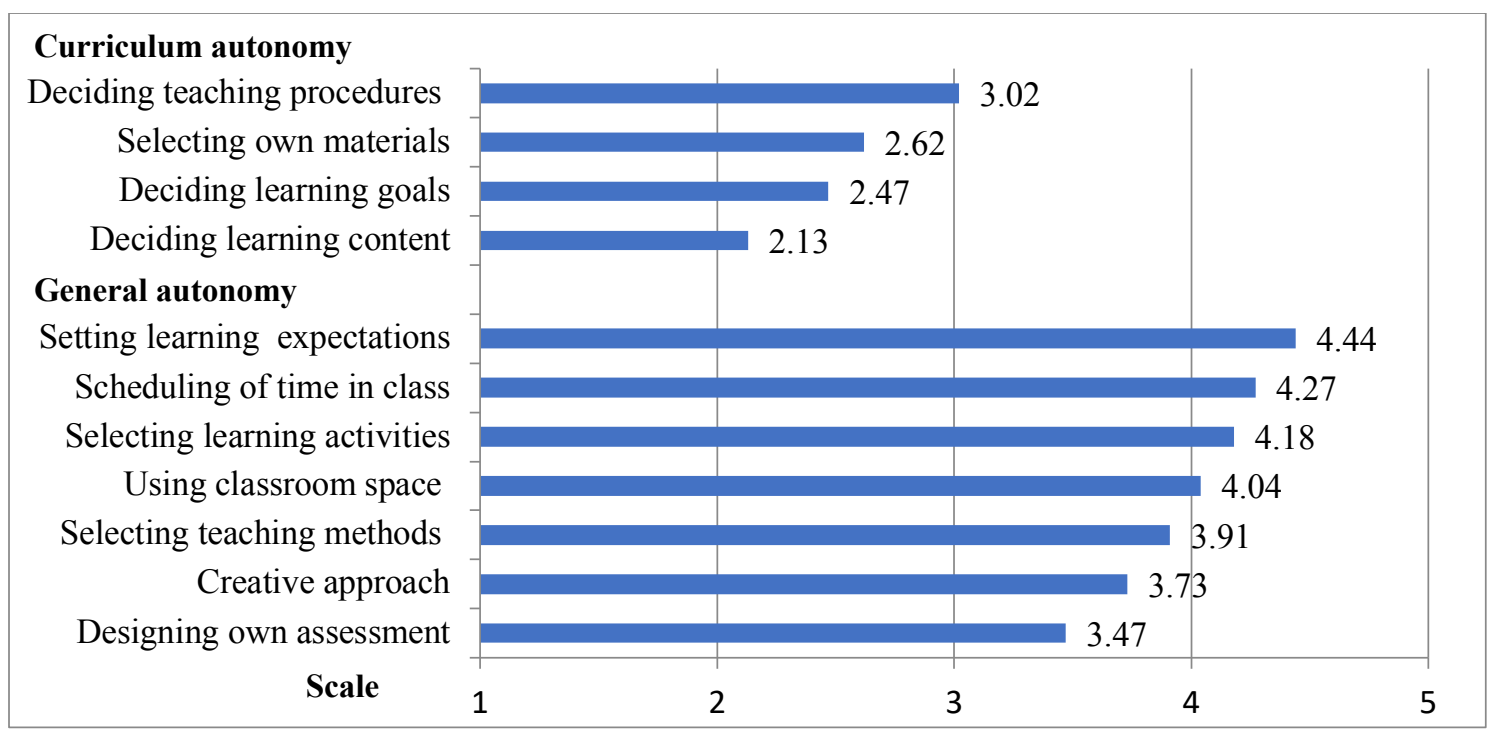

Fig 1. Teachers' autonomy level by construct $(\mathrm{N}=45)$

To determine if this difference was statistically significant, a Wilcoxon signed-rank test was used as the data were not normally distributed. The results indicated that the teachers scored themselves significantly higher for general autonomy than curriculum autonomy $(Z=-$ 
2.315, $p=0.021$ ), suggesting that they perceived themselves as having limited autonomy to make and implement curriculum-related decisions, but greater freedom to decide on day-today, classroom-related issues. Upcoming sections will explore how this unequal distribution of autonomy manifested in various aspects of the participants' teaching practice, drawing on the interview and observation data.

\subsubsection{Autonomy in selecting learning content and materials}

'Deciding learning content and learning goals' rated lowest among all aspects of teacher autonomy $(M=2.13, S D=0.66$ and $M=2.47, S D=0.69$ respectively), a finding which corresponded with the teaching practice of the observed and interviewed teachers. Hoai, Linh and Thanh all reported that teachers of the same courses were bound to the same syllabi, which, to ensure fairness and uniformity of course delivery, prescribed course objectives, course content and expected learning outcomes. More noticeably, curriculum design was often the purview of a small group of experienced senior teachers, leaving their junior colleagues with limited manoeuvrability in shaping, structuring and implementing curricula: 'The course outlines are designed by senior teachers who were once my teachers, and they have taught the courses so many times, so it has become an unwritten rule that we should follow them' (Linh).

Similarly, the surveyed teachers reported only limited autonomy to select their own materials $(M=2.62, S D=0.68)$. The three interview accounts provide explanatory detail about textbook selection: An experienced teacher, commonly head of a teaching section in the department, would select textbooks from among commercially available English learning materials. The selection process largely eschewed consultation with the teachers in direct charge of the courses, so selected materials were often a poor fit for learning and teaching requirements. An additional bugbear was MOET's decision to adopt the Common European Framework of Reference (CEFR) as a measure of language proficiency at university level, leading to disruptive, sweeping changes in curricula, syllabi, assessment and teaching materials - in Thanh's case, twice in four years. These findings resonate with those of Duong (2005), who reported on the mismatch between the content of a Vietnamese university's BA English curriculum, its associated learning materials, and students' needs. Duong argued that the mismatch was founded in teachers' limited capacity to make curriculum-related decisions and select learning materials. Similar restrictions regarding syllabus design were reported in Benson's (2010) study of Hong Kong teachers of English, though at secondary rather than tertiary level. 
The lack of curriculum autonomy rankled with Hoai, who convened teaching methodology courses for trainee English educators in her department. She bemoaned the mismatch between theory on textbook selection and evaluation which she conveyed to her students, and the reality that they would encounter as secondary-level English teachers: 'Most of them probably are going to teach in the formal education system, where a textbook series designed by MOET is used across all levels. They won't have a choice' (Hoai). Her concern echoes B. Nguyen and Crabbe's (1999) findings about constraints on material selection at secondary school level in Vietnam. It also speaks to the multiple layers of complexity in language teaching (Freeman, 2016) and the unfeasibility of a uniform approach to curriculum and materials. In Hoai's case, her own lack of autonomy in selecting course content and materials predicted potential constraints faced by her students in their own teaching careers.

Faced with these restrictions, Thanh and Hoai managed to create spaces for their curriculum autonomy (cf. Benson, 2010), such as by supplementing the prescribed textbook materials with self-selected resources. Thanh reported following the set syllabus and textbook for the first half of a class to ensure compliance with departmental content requirements and to assure students she was not deviating excessively from the set curriculum. Thereafter she provided self-sourced materials which she judged to be relevant to students' language proficiency and interests. Linh, however, was more apprehensive about deviating from the set curriculum:

How could I go to a senior teacher who designs a course syllabus and say to her, 'I think you should change this and that'? In Vietnamese culture we have this characteristic called 'harmony', and I think doing that would affect the harmony between me and my teachers or colleagues. Besides, I was not in a position to determine course contents, so what I wanted to do was out of my ability. That was also an obstacle against application of new knowledge and skills.

Interestingly, the interviewees struggled more with this lack of freedom after their return from overseas training than they had previously. Post-training, Thanh questioned her previously phlegmatic attitude to restrictions in selecting content and materials. She now found these galling, particularly as they were an established part of the education system and therefore difficult to change.

Once you're in the [education] system, you have to get accustomed to how it works. It's not the other way around... This may not be much of a problem if you always stay in that system, but if you've ventured out and known better and now returned, which is my case, it becomes more difficult... 
Linh, reflecting on her own experience of studying in the USA, remarked that teachers in US programs wielded considerable autonomy in terms of deciding course goals, selecting resources, and modifying content based on learner feedback, provided their teaching met the overall learning objectives mandated by their departments or institutions. The marked contrast with her home teaching context led Linh to conclude that 'I don't think teachers in our context have much autonomy'. Evidently, the participants' training in Inner-Circle TESOL programs highlighted for them the schism in autonomy between Anglophone training environments and their own local context, precipitating a sense of 'disillusion' (cf. Liyanage $\&$ Bartlett, 2008, p. 1827) with the latter.

\subsubsection{Autonomy in designing course assessment}

As the interview data reveal, a key factor behind the teachers' reluctance to modify prescribed teaching resources was the assessment items which were consistent across classes. This helps explain why questionnaire respondents rated their freedom to design their own assessment tasks so unfavourably (At 3.47, the mean rating for this item is the lowest of all items measuring general autonomy). Interviewees reported that end-of-semester assessment tasks (primarily formal, closed-book examinations) were taken from a 'test bank' and administered across the cohort. Individual teachers could design their own localized in-class tests, but in practice they tended to model these on standardized CEFR tests to familiarize students with the CEFR examination format. The interviewees expressed concern for students' performance in examinations, opining that these outcomes reflected their own effectiveness as educators. Thanh commented: 'I don't want my students' grades to be lower than students in other classes just because they don't know the test format well. I also want to maintain the uniformity in assessment between my class and others'.

This restriction in assessment types also informed Linh's teaching practice, as the key instructional episode below (from observation notes taken in a speaking course) illustrates:

The teacher pairs up students and asks each pair to do a picture description task that resembles a task in the final exam (B1 type of activity according to CEFR levels). The teacher first hands each pair a picture with a few questions as prompts. After one minute of preparation, the pairs make a conversation based on the given picture, which depicts several activities for a summer holiday in a beachside city. They discuss and decide on three activities they would like to do together. The students seem familiar with the task and talk for more than three minutes. At the end of each presentation, the teacher compliments the students on their strong points, and provides correction about 
their pronunciation and word choice. The students are also given a detailed evaluation worksheet, in which their performance is evaluated on a 1-5 rating scale based on fluency, accuracy, vocabulary choice, and interaction.

This segment foregrounds the influence of external assessment practices on Linh's pedagogical decision-making. Linh had recently made this type of exam-oriented activity a routine in her speaking course to better prepare her students for oral examinations, but she was well aware that it neither interested nor motivated them. She also questioned the authenticity of the activity, which was based on a CEFR B1-level speaking task: 'I am very doubtful about whether the students would have to describe pictures that frequently when they use English in real life contexts'. So although Linh did wield some autonomy in in-class assessment, she tended to direct this autonomy toward preparation for formal examinations rather than a targeted evaluation of her own students' unique linguistic competencies. Overall, the outcome of this classroom observation, together with the participants' low ratings for autonomy in assessment, suggests that assessment constraints might negatively impact their teaching practice (Everhard \& Murphy, 2015). In particular, despite perceiving that they possessed autonomy in assigning assessment tasks, the participants nonetheless directed their efforts toward uniformity with other teachers so as not to disadvantage their students.

\subsection{Teachers' individual autonomy and the impact of overseas training}

Despite constraints in terms of curriculum-related decision-making, the teachers valued the classroom as a milieu which afforded them a higher degree of teaching autonomy. As Section 5.1 reports, the highest perceived autonomy ratings were linked to classroom-related issues such as having freedom to set expectations for students' learning $(M=4.44, S D=0.59)$, controlling the use of time in class $(M=4.27, S D=0.54)$, and controlling the selection of learning activities $(M=4.18, S D=0.61)$ (see Figure 1). The interviewees relished having freedom to design their own teaching activities, because of the opportunity to utilize knowledge and skills acquired from overseas training. Thanh, for instance, was able to implement a peer-assessment process for some in-class assessment items, a practice which made her students more critical of their own learning and that of their classmates. She attributed this to increased knowledge of assessment practices gained from her TESOL study in Australia. 
Autonomy was also exhibited in teachers' setting expectations for student learning. Hoai's instructional episode during a methodology course on materials development is illustrative:

The students are given an application exercise on textbook evaluation and adaptation. In six groups of five, they discuss and evaluate one English textbook used in the formal education system according to a pre-assigned criterion of textbook evaluation (e.g., method, instruction, syllabus, topics, cultural appropriateness, etc.). The teacher asks students beforehand to always bring with them an English textbook to use in class activities. She directs their attention to the text's pedagogical shortcomings. After each group has presented their evaluation, the teacher challenges them by asking why and how a particular textbook can be improved. She repeatedly encourages them to be more critical in their evaluation. This seems effective as the last two groups are able to point out many limitations of their evaluated textbooks, as well as give suggestions on how to adapt them.

This episode demonstrates a teaching practice that emphasized both student autonomy (students sourcing materials for class activities) and critical thinking (about the quality of sourced materials). Hoai keenly advocated both factors in her teaching, being aware of the importance of student autonomy and independent thought. She credited her approach to the influence of her TESOL program in the USA:

The MA program in the US has definitely influenced my teaching practice in this sense. The education system in Vietnam does not emphasize critical thinking but as classroom teachers, we can make some small changes by making students think critically and provoking their thinking.

The participants' high self-ratings of individual autonomy, their interview accounts, and the excerpts from their instructional practice all point to greater autonomy in classroom teaching than in curriculum-related matters. The application of knowledge and skills gained in teacher education programs was also demonstrated better in day-to-day teaching activities. This finding recalls previous research on implementation of knowledge and skills gained from teacher education (e.g., Benson, 2010; Li \& Edwards, 2011), where despite structural constraints, returning teachers were still keen to put their new skill-set into practice.

\subsection{Participants' autonomy as teacher-learners}

The interviewees reflected that the emphasis on self-direction in their overseas teacher education programs had helped shape them into autonomous learners. Hoai and Linh both 
reported being able to self-select courses from lists of electives in their training programs, and to choose their preferred assignment topics. Members of Thanh's cohort were able to propose their own deadlines for assessment items, and self- and peer assessment featured prominently in learning activities. Faculty members' teaching styles were another factor in fostering autonomy: One of Thanh's lecturers always addressed his students as 'colleagues', acknowledging that they shared his profession and possessed qualifications and experience. She commented: 'I had a feeling that all of us in that course were taking part in a professional development workshop rather than learning a course. Our opinions were highly valued'. These factors exemplify a 'pedagogy for autonomy' across the Inner-Circle teacher education programs (Jiménez Raya \& Vieira, 2015; Smith \& Erdogan, 2008), although it would be premature to speculate whether staff on the programs consciously oriented to teacher autonomy as 'a goal in its own right' (Smith \& Erdogan, 2008, p. 86).

One unfortunate omission in the training programs, however, was that the pedagogical, social and economic constraints which would characterize teaching in local contexts post-training were almost never discussed explicitly by staff. To the trainees, this was the metaphorical elephant in the room: They were well aware of potential issues in applying their new-found knowledge even before returning to their teaching context, and they desired critical discussion of these issues and feasible pathways toward positive outcomes. These were not forthcoming.

\section{Discussion}

Mapping against the guiding questions set out in Section 3.3, this section discusses the key findings emerging from the data: (1) Teachers' constraints in exercising teacher autonomy; (2) their capacity to adapt and flexibility in exercising autonomy; and (3) the impact of their Inner-Circle teacher education programs on shaping their teacher autonomy. Finally, implications for the various stakeholders in TESOL professional development are considered.

\subsection{Constraints in exercising teacher autonomy}

Findings of the present study reveal numerous constraints faced by the teacher participants in attempting to exercise both structural and individual aspects (see Section 1.1) of their autonomy as teachers (Benson, 2010; McGrath, 2000). Regarding structural features, the teachers were limited by curriculum-related aspects of their teaching practice, bound to a syllabus that prescribes course objectives and teaching resources. This might reflect the often highly-structured, top-down nature of Vietnam's tertiary institutions (Author, 2017; Nunan \& 
Lamb, 1996), where the construction and ratification of curricula is the province of MOET rather than individual universities (Hayden \& Lam, 2007). This resonates with the experience of teachers reported in previous teacher autonomy research (see Benson, 2010; La Ganza, 2008) as well as the expectations of TESOL teachers from Malaysia, Vietnam, and other Asian countries returning to their local institutions from overseas training (Erlam, 2014; Phan, 2008; Yeh, 2011). Furthermore, the participants in the present study were concerned about the need for their practice to conform to the curriculum and pedagogical requirements of their departments and wider institutions, which were in place to maintain uniformity among teachers on a given course. Jiménez Raya and Vieira (2015) are critical of such vertical models: They decry standardized educational environments which 'decontextualize knowledge' (p. viii), where schools are managed like factories, teachers are expected to all target the same instructional outcomes, and students are required to learn the same content at the same pace in the same order, thus depriving teachers of meaningful professional freedom.

The participants were also required to conform to assessment practices that they had no freedom to decide or change, contributing to a negative washback effect wherein instructors laid undue emphasis on content that targeted upcoming testing items (viz. Linh's efforts to incorporate exam-oriented classroom activities into her teaching plans). This finding supports Everhard and Murphy's (2015) contention that assessment can bidirectionally influence autonomy: promoting autonomy if the assessment method allows for learners' self-adjustment, self-monitoring, and higher order thinking, but degrading it if assessment creates heavy reliance on others' judgments. The participants' obligation to abide by externally-prescribed assessment practices with which they did not identify, unarguably reduces their professional autonomy.

In the present study, the issue of professional trust (Van Maele \& Van Houtte, 2012) also arises. Designing course syllabi and selection of learning resources were entrusted to more experienced teachers, leaving younger and less experienced ones without input - or, crucially, investment - into the decision-making process. This practice is now generally considered unsound (Blasé \& Blasé, 1998): Supporting early-career teachers' professional judgment is deemed key to increasing their confidence and their competence as educators. The lack of professional trust evidenced in the current study is likely a function of the participants' local sociocultural context, where traditionally age and experience are central to one's professional status (see Tran, 1997); nevertheless, the type of progress Vietnam mandates in policies such as the NFL2020 project necessitates reform so that teachers' value can derive solely from their professional competence. 
Another demonstration of structural constraints that emerges is that the participants' practice was indirectly impacted by reforms in national foreign language education policy. The NFL2020 Project and MOET's adoption of the CEFR as an evaluation benchmark were mentioned several times by participants, though mostly as causative factors underlying the curricular and pedagogical constraints they were bound by, rather than direct involvement in the reform process. As ground-level enactors of this policy, the participants were concerned about the potentially adverse shifts in approach to resource selection and assessment that the policy engendered, rather than being appreciative of positive aspects of the renovation. Their reaction mirrors that of teachers in V. H. Nguyen and Hamid's (2015) study with university English teachers in Vietnam, who remarked that the benefits of employing the new competency framework were overshadowed by the realities that they faced in their teaching practice, such as the gap between students' actual proficiency level and the standards they were expected to reach, and the paucity of CEFR-based learning and testing resources. This reflects La Ganza's (2008) claim that teacher autonomy is likely affected by forces that are external to the institution but which potentially impinge on the professional freedom of ground-level teachers. In the context of the current study, these forces take the form of educational policies instituted at the macro- (governmental) level but which fail to account for local economic, pedagogical, or socio-cultural realities or course/program objectives (Author, 2017), reflecting a 'lack of community consultation or input in most language-ineducation decisions' (Kaplan \& Baldauf, 2005, p. 620).

The present research also revealed that certain of the participants' cultural characteristics may have prevented them from actively exercising their individual teaching autonomy. Linh, for example, was reluctant to depart from a prescribed pedagogical trajectory, citing the Vietnamese cultural feature of respecting harmony in relationshipbuilding as the reason for not flouting traditional teaching practice. Her apprehension about upsetting her senior colleagues as well as affronting the established teaching system and her decision to keep to a harmonious solution arguably constrained her from exercising a greater degree of teaching autonomy. Again, there is a precedent: Phan's (2008) and Pham's (n.d.) research with Australian-trained Vietnamese teachers of English at tertiary level found that, notwithstanding their study in an Inner-Circle academic environment, they continued to uphold Vietnamese cultural features such as reluctance to raise questions to their lecturers or voice their opinions in class discussions. These cultural characteristics are by no means universal or immutable, but may nevertheless have 'influenced and constrained' (Phan, 2008, p. 27) the teacher-trainees' performance in their program. 


\subsection{Teachers' adaptation and flexibility in exercising autonomy}

The participants' high self-reported general (classroom-based) autonomy was evidence of their ability to operate within the confines of a set institutional structure, creating what Benson (2010, p. 270) terms 'spaces for teacher autonomy'. Similar findings are reported in Benson's (2010) study of Hong Kong teachers of English, and Erlam's (2014) study of the Malaysian context). Furthermore, in the present study the spaces which the participants created were geared to promote not just teacher autonomy but learner autonomy, exemplified by Hoai and Thanh's attempts to promote learner self-assessment and critical thinking in their classes. The teachers' classroom autonomy thereby promoted the learner autonomy of their students, supporting Little's $(1995,2000)$ argument that learner autonomy is a key constituent of teacher autonomy.

\subsection{The efficacy of teacher training programs on participants' teacher autonomy}

We here weigh up the efficacy of the participants' TESOL teacher education programs in shaping their teacher autonomy. As Benson (2010) argues, bridging the gap between what is desired and what is practicable in the local pedagogical context depends on teachers' freedom and capacity to experiment with approaches, methods and techniques learned during their training; hence the centrality of teacher education for enhancing teachers' sense of professional autonomy. Crucially, the present research pinpoints two contrasting ways in which overseas training influenced the participants' perceived and exercised autonomy in its various dimensions (see Section 3.2). On the one hand, the knowledge gained from teacher training empowered them to experiment with new teaching approaches, methods and techniques, making their practice more creative and autonomous and thus enhancing their individual autonomy (cf. Benson, 2010). But on the other, their training gave them the tools to critically reflect on the limited nature of their structural autonomy and the local contextual constraints which inhibited its development. It also illuminated the lack of 'fit' between the content taught and applied in training programs in Anglophone countries, and the local conditions in which they themselves operated.

Another crucial finding is that during their teacher training programs the participants were empowered to exercise their autonomy as learners, e.g., through self-assessment of learning and through positioning as professional equals with staff and classmates, affirming Little's (1995) notion of enhancing teacher-trainees' autonomy by educating them in an autonomous manner. What teacher training did not do, according to the present study's 
findings, was empower - or at least guide - teachers to operate autonomously within local constraints and create more spaces to exercise their teaching autonomy. This seems an incongruous omission given the large number of teacher-learners from Outer and Expanding Circle countries attending such programs (36\% of a cohort according to Llurda's 2005 study, $78 \%$ of whom intended to return to their country to teach; see also England \& Roberts, 1989; Liu, 1999). But in fact, the failure of Inner Circle TESOL programs to address the issues and challenges confronting trainees from overseas who plan to teach in their own countries has been noted often in research (e.g. Canagarajah, 2005; Holliday, 2005; Oka, 2004). Lack of sufficient context-specific knowledge may be to blame: Macalister's (2011) investigation of New Zealand-based teacher trainers training Malaysian pre-service teachers found that the New Zealand educators largely taught from their own perspective and experience, and possessed little knowledge or experience of the Malaysian education system. Clearly this is an area for further inquiry leading to modified practice.

Having raised these issues, the following section suggests how TESOL-training practitioners and other involved parties might address them.

\subsection{Implications for TESOL training programs and local stakeholders}

Given the light shed here on the limited teaching autonomy of overseas-trained TESOL teachers in Vietnam, there are clear implications for the various stakeholders involved in TESOL professional development, in particular: (1) designers and deliverers of Inner-Circle TESOL programs; and (2) macro- and meso-level stakeholders whose decisions impact on TESOL teachers' day-to-day practice, such as creators of educational policy and institutional supervisors. We explore these here.

For TESOL teacher training programs to foster teacher autonomy despite the various constraints identified in this study, training might encompass Jiménez Raya and Viera's (2015) 'pedagogy for autonomy' (see Section 3.2). This is achieved in practice through jointnegotiation processes similar to those for enhancing learner autonomy in language classrooms: Firstly, involving course participants in determining course aims and content; and secondly, in co-designing learning resources and assessment tasks (cf. Little, 1995; Smith \& Erdogan, 2008). Key to the successful implementation of such an initiative is a paradigm shift among teacher educators. Kumaravadivelu (2006) encourages teacher educators to move beyond the traditional producer-consumer model of knowledge delivery, empowering teacher trainees to exercise their own autonomy, drawing on their qualifications and experience to transform the learning process from a unidirectional, decontextualized exercise to a context- 
laden, jointly-constructed sharing of knowledge. Inner-Circle TESOL training programs would also benefit from coming to grips with some of the pedagogical and institutional constraints which teacher-trainees will face on exit, thereby further empowering teachers from the Expanding Circle to create more spaces for manoeuvre within these confines. Specifically, teacher trainers can foster critical discussion among trainees from various polities about possible structural and contextual constraints that returning teachers might face and have trainees jointly facilitate possible solutions as part of their course content and/or assessment.

Additionally, the present findings illuminate the impact on TESOL teachers' professional autonomy by external actors, particularly creators of educational policy and institutional supervisors. Firstly, Inner-Circled-trained TESOL teachers' enhanced knowledge and skills would be optimally utilized if teachers were permitted greater autonomy in tasks of syllabus design and resource/materials development. After all, a key reason why Vietnam's government shoulders the expense or solicits foreign governmental aid to send English language educators overseas for further training is so that their newly-acquired expertise can be applied locally, benefitting their institution and their students, whose bilingual careers will in turn propel Vietnam's burgeoning economy. And their training contributes to the objectives of the NFL2020 project: High-quality English language education by qualified and experienced staff with advanced English language proficiency. So it makes sense for their training to be put to the most beneficial use on their return to the local institution rather than assigning the work solely on the basis of seniority, as is often the case. As Van Maele and Van Houtte (2012) acknowledge, trust is key here: relatively junior staff may work effectively with senior colleagues provided there is a culture of mutual trust in one another's competence and experience as educators. In the same vein, policy makers at the macro-level could allow greater latitude to individual institutions in terms of pedagogical practice at the program, course and classroom level. They might also benefit from reducing uncritical adherence to standardized assessment mechanisms (e.g., IELTS) and competency frameworks (e.g., CEFR) as benchmarks of educational success (Jiménez Raya \& Vieira, 2015).

\section{Concluding remarks}

This research examines the professional experience of Inner-Circle-trained English language teachers after returning to teach in their local contexts, taking teacher autonomy as the central point of investigation. It reveals structural, contextual, cultural and personal constraints that 
impacted their professional practice, and illuminates their struggle to create spaces within these constraints to exercise their professional freedom and promote their own and their learners' autonomy. While their overseas teacher training programs did facilitate teachers' autonomy via the transfer of knowledge and skills, they simultaneously problematized the teachers' existing perception of autonomy, triggering unfavourable comparisons between the relatively autonomous overseas learning environments and the often more rigid and confining local teaching contexts. The research both informs the professional experience of English language educators in comparable polities, and also speaks to the influence of macro- and meso-level stakeholders on these educators' professional development and their sense of autonomy.

We conclude by acknowledging some methodological limitations. First, the relatively small quantitative sample limits the generalisability of the study and may reduce the internal consistency of questionnaire items. Second, since the qualitative sample comprised participants from one university, their experience may not be representative of other returned teachers. Future research might profitably survey a larger sample and interview/observe participants from a range of institutions, ideally both public and private. Post-training teacher autonomy might also be explored in other Expanding Circle contexts in South East Asia and elsewhere, eventually leading to comparative studies of this important issue in language teacher education.

\section{References}

Author. (2017). [details removed for peer review]

Benson, P. (2006). Autonomy in language teaching and learning. Language Teaching, 40(1), 21-40. doi: 10.1017/S0261444806003958

Benson, P. (2010). Teacher education and teacher autonomy: Creating spaces for experimentation in secondary school English language teaching. Language Teaching Research, 14(3), 259-275. doi: 10.1177/1362168810365236

Benson, P. (2011). What's new in autonomy? The Language Teacher, 35(4), 15-18.

Benson, P. (2013). Teaching and researching: Autonomy in language learning. Abingdon, UK: Routledge.

Berg, B. L. (2007). Qualitative research methods for the social sciences. Boston, MA: Pearson Education Allyn \& Bacon.

Blasé, J. R., \& Blasé, J. (1998). Handbook of instructional leadership: How really good principals promote teaching and learning. Thousand Oaks, CA: Corwin.

Borg, S. (2006). Teacher cognition and language education: Research and practice: London, UK: Continuum. 
Brown, P., Smith, R., \& Ushioda, E. (2007). Responding to resistance. In A. Barfield \& S. H. Brown (Eds.), Reconstructing autonomy in language education: Inquiry and innovation (pp. 71-83). London, UK: Palgrave Macmillan.

Butler, Y. G. (2011). The implementation of communicative and task-based language teaching in the Asia-Pacific region. Annual Review of Applied Linguistics, 31, 36-57.

Canagarajah, A. S. (Ed.) (2005). Reclaiming the local in language policy and practice. Mahwah, NJ: Lawrence Erlbaum.

Chowdhury, R., \& Phan, L. H. (2008). Reflecting on Western TESOL training and communicative language teaching: Bangladeshi teachers' voices. Asia-Pacific Journal of Teacher Education, 28(3), 305-316.

Chowdhury, R., \& Phan, L. H. (2014). Desiring TESOL and international education: Market abuse and exploitation. Bristol, UK: Multilingual Matters.

Creswell, J. W., \& Plano Clark, V. L. (2007). Designing and conducting mixed methods research. Thousand Oaks, CA: SAGE Publications.

Denham, P. A. (1992). English in Vietnam. World Englishes, 11(1), 61-69. doi:10.1111/j.1467-971X.1992.tb00047.x

Do, H. T. (1996). Foreign language education policy in Vietnam: The reemergence of English and its impact on higher education. (Dissertation/Thesis), ProQuest, UMI Dissertations Publishing.

Dogancay-Aktuna, S., \& Hardman, J. (2012). Teacher education for EIL: working toward a situational meta-praxis. In A. Matsuda (Ed.), Principles and practice of teaching English as an international language (pp. 103-118). Bristol, UK: Multilingual Matters.

Dörnyei, Z. (2007). Research methods in applied linguistics: Quantitative, qualitative, and mixed methodologies. Oxford, UK: Oxford University Press.

Dudzik, D., \& Nguyen, T. N. Q. (2015). Vietnam: Building English competency in preparation for ASEAN 2015. In R. Stroupe \& K. Kimura (Eds.), ASEAN integration and the role of English Language teaching (pp. 41-71). Phnom Penh, Cambodia: Language Education in Asia.

Duong, T. H. O. (2005). Meeting students' needs in a B.A. English program in Vietnam. Teacher's Edition, 20-26.

England, L., \& Roberts, C. (1989). A survey of foreign students in MA-TESOL programs. Presented at the Teachers of English to Speakers of Other Languages Conference, San Antonio, TX. (ERIC Document Reproduction Service No. 306 754.)

Erlam, R. (2014). Affordances and constraints: Training language teachers in New Zealand for the Malaysian context. New Zealand Studies in Applied Linguistics, 20(1), 5-20.

Everhard, C. J., \& Murphy, L. (2015). Assessment and autonomy in language learning. Basingstoke, UK: Palgrave Macmillan.

Freeman, D. (2009). The scope of second language teacher education. In A. Burns \& J. C. Richards (Eds.), The Cambridge guide to second language teacher education (pp. 1119). New York: Cambridge University Press.

Freeman, D. (2016). Educating second language teachers. Oxford: Oxford University Press. Hayden, M., \& Lam, Q. T. (2007). A 2020 vision for higher education in Vietnam. International Educator, 16(1), 14-17.

Hoang, V. V. (2010). The current situation and issues of the teaching of English in Vietnam. Ritsumeikan Languages and Cultures, 22(1), 1-18.

Holliday, A. (1994). Appropriate methodology and social context. Cambridge, UK: Cambridge University Press.

Holliday, A. (1998). Evaluating the discourse: The role of applied linguistics in the management of evaluation and innovation. In P. Rea-Dickins \& K. P. Germaine (Eds.), 
Managing evaluation and innovation in language teaching: Building bridges (pp. 195219). New York: Longman.

Holliday, A. (2005). The struggle to teach English as an International Language. Oxford: Oxford University Press.

Jiménez Raya, M., \& Vieira, F. (2015). Enhancing autonomy in language education: A casebased approach to teacher and learner development. Berlin, Germany: De Gruyter Mouton.

Kachru, B. (1985). Standards, codification and sociolinguistic realism: The English language in the outer circle. In G. Quirk \& H. G. Widdowson (Eds.), English in the world: Teaching and learning the language and literatures (pp. 3-22). Cambridge, UK: Cambridge University Press.

Kaplan, R. B., \& Baldauf, R. B. (2005). Language-in-education policy and planning. In E. Hinkel (Ed.), Handbook of research in second language teaching and learning (pp. 609-622). Abingdon, UK: Routledge.

Kirkpatrick, A. (2012). English in ASEAN: Implications for regional multilingualism. Journal of Multilingual and Multicultural Development, 33(4), 331344.

Kumaravadivelu, B. (2006). Understanding language teaching: from method to post-method. Mahwah, NJ: Lawrence Erlbaum Associates.

La Ganza, W. (2008). Learner autonomy - teacher autonomy: Interrelating and the will to empower. In T. Lamb \& H. Reinders (Eds.), Learner and teacher autonomy: Concepts, realities, and responses (pp. 63-82). Amsterdam, the Netherlands: John Benjamins.

Lamb, T. (2008). Introduction to this volume. In T. Lamb \& H. Reinders (Eds.), Learner and teacher autonomy: concepts, realities, and responses (pp. 5-14). Amsterdam, the Netherlands: John Benjamins.

Li, D., \& Edwards, V. (2013). The impact of overseas training on curriculum innovation and change in English language education in Western China. Language Teaching Research, 17(4), 390-408. doi:10.1177/1362168813494124

Li, D., \& Edwards, V. (2014). English language teaching and educational reform in Western China: A knowledge management perspective. System, 47, 88-101. doi:10.1016/j.system.2014.09.019

Little, D. (1995). Learning as dialogue: The dependence of learner autonomy on teacher autonomy. System, 23(2), 175-181.

Little, D. (2000). Autonomy and autonomous learners. In M. Byram (Ed.), Routledge encyclopedia of language teaching and learning (pp. 69-72). London, UK: Routledge.

Liu, D. (1999). Training non-native TESOL students: Challenges for TESOL teacher education in the West. In G. Braine (Ed.), Non-native educators in English language teaching (pp. 197-210). Mahwah, NJ: Lawrence Erlbaum.

Liyanage, I., \& Bartlett, B. J. (2008). Contextually responsive transfer: Perceptions of NNES on an ESL/EFL teacher training programme. Teaching and Teacher Education, 24(7), 1827-1836. doi:10.1016/j.tate.2008.02.009

Llurda, E. (2005). Non-native TESOL students as seen by practicum supervisors. In E. Llurda (Ed.), Non-native language teachers: Perceptions, challenges, and contributions to the profession (pp. 131-154). New York: Springer.

Macalister, J. (2011). Teaching with information texts: Comparing the beliefs of Malaysian and New Zealand trainers. Language Education in Asia, 2(1), 56-70.

Macalister, J. (2016). Tracing it back: identifying the impact of a trans-national language teacher education programme on classroom practice. RELC Journal, 47(1), 59-70. 
McGrath, I. (2000). Teacher autonomy. In B. Sinclair, I. McGrath \& T. Lamb (Eds.), Learner autonomy, teacher autonomy: Future directions (pp. 100-110). London, UK: Longman.

McKnight, A., \& Turner, L. (1995). TESOL in developing countries: Challenges for teacher education. Paper presented at the Annual Meeting of the Teachers of English to Speakers of Other Languages, Long Beach, CA, USA.

Nguyen, B., \& Crabbe, D. (1999). The design and use of English language textbooks in Vietnamese secondary schools. Proceedings from Language and Development Conference. Hanoi, Vietnam.

Ngo, T. H. (2015). An Investigation into Students' Motivation to Learn English in Higher Education in Vietnam. (Doctor of Philosophy), Queensland University of Technology. Retrieved from http://eprints.qut.edu.au/84470/1/Thu\%20Huong_Ngo Thesis.pdf

Nguyen, T. H., Fehring, H., \& Warren, W. (2014). EFL teaching and learning at a Vietnamese university: What do teachers say? English language teaching, 8(1), 22-31. doi:http://dx.doi.org/10.5539/elt.v8n1p31

Nguyen, T. M. H. (2011). Primary English language education policy in Vietnam: insights from implementation. Current Issues in Language Planning, 12(2), 225-249. doi:10.1080/14664208.2011.597048

Nguyen, V. H., \& Hamid, O. (2015). Educational policy borrowing in a globalized world. English Teaching: Practice \& Critique, 14(1), 60-74.

Nunan, D., \& Lamb, C. (1996). The self-directed teacher: Managing the learning process. Cambridge, UK: Cambridge University Press.

Oka, H. (2004). A non-native approach to ELT: Universal or Asian? Asian EFL Journal, $6(1), 1-8$.

Park, G. (2012). "I am never afraid of being recognized as an NNES": One teacher's journey in claiming and embracing her nonnative-speaker identity. TESOL Quarterly, 46(1), 127-151.

Pearson, L. C., \& Hall, B. W. (1993). Initial construct validation of the Teaching Autonomy Scale. The Journal of Educational Research, 86(3), 172-178.

Pearson, L. C., \& Moomaw, W. (2006). Continuing validation of the Teaching Autonomy Scale. The Journal of Educational Research, 100(1), 44-51.

Pennycook, A. (2003). Global Englishes, Rip Slyme, and performativity. Journal of Sociolinguistics, 7(4), 513-533. doi:10.1111/j.1467-9841.2003.00240.x

Pham, H. H. (2004). Trained in the West, teaching in the East: Vietnamese teachers returning from TESOL courses abroad. (Doctoral thesis, University of Melbourne, Melbourne, Australia.)

Pham, H. H. (unpublished results). Impact of Australian training on professional practices: A case study of Vietnamese teachers of English.

Phan, L. H. (2008). Teaching English as an international language: Identity, resistance and negotiation. Clevedon, UK: Multilingual Matters.

Smith, R. (2003). Teacher education for teacher-learner autonomy. In J. Gollin, G. Ferguson, \& H. Trappes-Lomax (Eds.), Symposium for Language Teacher Educators: Papers from Three IALS Symposia (CD-ROM). Edinburgh: IALS, University of Edinburg.

Smith, R., \& Erdogan, S. (2008). Teacher-learner autonomy: Programme goals and studentteacher constructs. In T. Lamb \& H. Reinders (Eds.), Learner and teacher autonomy: Concepts, realities, and responses. Amsterdam, the Netherlands: John Benjamins.

Socialist Republic of Vietnam. (2008). Teaching and learning languages in the national educational system, 2001-2020. Retrieved on 15 August, 2015 from http://thuvienphapluat.vn/archive/Quyet-dinh/1400-QD-TTg-vb83815t17.aspx. 
Strauss, A. L., \& Corbin, J. M. (1990). Basics of qualitative research: grounded theory procedures and techniques. Newbury Park, CA: Sage Publications.

Teddlie, C., \& Tashakkori, A. (2009). Foundations of mixed methods research: Integrating quantitative and qualitative approaches in the social and behavioral sciences. Thousand Oaks, CA: Sage Publications.

Tran, N. T. (1997). The basics of Vietnamese culture. Hanoi, Vietnam: Education Publishing House.

Trebbi, T. (2008). Language learner autonomy in a Norwegian context. In J. Miliander \& T. Trebbi (Eds.), Educational policies and language learner autonomy in schools: A new direction in language education (pp. 40-52). Dublin, Ireland: Authentik.

UNESCO Institute for Statistics. (2009, July). Global flow of tertiary level students. Retrieved on 11 July, 2015 from http://www.uis.unesco.org/Education/Pages/international-student-flow-viz.aspx

Van Maele, D., \& Van Houtte, M. (2012). The role of teacher and faculty trust in forming teachers' job satisfaction: Do years of experience make a difference? Teaching and Teacher Education, 28(6), 879-889.

Vietnam International Education Department (VIED). (2016). Mission and responsibilities. Retrieved from http://vied.vn/vi/gioi-thieu/chuc-nang-nhiem-vu.html

Wright, S. (2002). Language education and foreign relations in Vietnam. In J. Tollefson (Ed.), Language policies in education: Critical issues (pp. 225-244). Mahwah, NJ: Erlbaum.

Yeh, H. (2011). EFL teachers' challenges and dilemmas in transferring theories and practices cross-culturally. Asia Pacific Education Review, 12, 97-104.

\section{Appendix A}

Teacher Autonomy Survey

Adapted from Pearson and Moomaw (2006)

\begin{tabular}{|l|l|l|l|l|l|}
\hline After getting a higher degree in TESOL & \multicolumn{3}{|c|}{$\begin{array}{l}\text { strongly } \\
\text { disagree } \\
\text { agree }\end{array}$} \\
\hline 1. In my teaching, I use my own guidelines and procedures. & 1 & 2 & 3 & 4 & 5 \\
\hline 2. I have little say over the content and skills that are selected for teaching. & 1 & 2 & 3 & 4 & 5 \\
\hline 3. My teaching focuses on those goals and objectives I select myself. & 1 & 2 & 3 & 4 & 5 \\
\hline 4. The materials I use in my class are chosen for the most part by me. & 1 & 2 & 3 & 4 & 5 \\
\hline 5. I am free to be creative in my teaching approach. & 1 & 2 & 3 & 4 & 5 \\
\hline 6. The selection of student-learning activities in my class is under my control. & 1 & 2 & 3 & 4 & 5 \\
\hline 7. The scheduling of use of time in my classroom is under my control. & 1 & 2 & 3 & 4 & 5 \\
\hline 8. I have limited control over how classroom space is used. & 1 & 2 & 3 & 4 & 5 \\
\hline 9. I select the teaching methods and strategies I use with my students. & 1 & 2 & 3 & 4 & 5 \\
\hline 10. The evaluation and assessment activities used in my class are selected by others. & 1 & 2 & 3 & 4 & 5 \\
\hline 11. I have the freedom to set expectations for student learning. & 1 & 2 & 3 & 4 & 5 \\
\hline
\end{tabular}




\section{Appendix B}

Interview schedule

Individual interview schedules were developed for each interviewee based on their earlier survey responses and analysis of the survey results. The following are common questions asked of all three interviewees.

1. Explain your ratings for your level of autonomy in curricular aspects of teaching (e.g., selecting learning goals, content and materials).

2. Explain your ratings for your level of autonomy in general aspects of teaching (e.g., selecting teaching methods and learning activities).

3. Give an example of a teaching incident when you feel you can exercise your teacher autonomy, and one in which you feel you do not have much autonomy. What do like/dislike about these experiences?

4. Have you ever wished that you had more freedom to make teaching- and learningrelated decisions?

5. How much autonomy do you think your teachers/professors in the Inner-Circle TESOL programs you attended had in their teaching?

6. Were you allowed to be autonomous while you were learning in the Inner-Circle TESOL programs? If yes, can you give an example? If no, why do you think that you were not encouraged to be an autonomous learner? 